\title{
Nursing diagnosis: educational strategy based on problem-based learning ${ }^{1}$
}

\author{
Ana Luisa Brandão de Carvalho Lira²
}

Marcos Venícios de Oliveira Lopes ${ }^{3}$

This study aimed to evaluate the effectiveness of a teaching strategy on nursing diagnoses based on problem-based learning in the performance of clinical reasoning and diagnostic trial of undergraduate students. Experimental study conducted in two phases: content validation of problems and implementation of educational strategy. The results showed improvement in the data pooling ability of students in the experimental group. It is concluded that the strategy put in practice exerted a positive influence.

Descriptors: Nursing; Nursing Diagnosis; Teaching; Problem-Based Learning.

\footnotetext{
${ }^{1}$ Paper extrated from Doctoral Dissertation "Ensino de diagnóstico de enfermagem: uma estratégia educativa fundamentada na aprendizagem baseada em problemas" presented to Universidade Federal do Ceará, Fortaleza, CE, Brazil.

2 RN, Ph.D. in Nursing, Adjunct Professor I, Departamento de Enfermagem, Universidade Federal do Rio Grande do Norte, Natal, RN, Brazil. E-mail: analira@ufrnet.br.

${ }^{3}$ RN, Ph.D. in Nursing, Adjunct Professor IV, Departamento de Enfermagem, Universidade Federal do Ceará, Fortaleza, CE, Brazil. E-mail: marcos@ufc.br.
}

Corresponding Author:

Ana Luisa Brandão de Carvalho Lira

Universidade Federal do Rio Grande do Norte. Departamento de Enfermagem

Campus Universitário, BR 101, s/n

Bairro: Lagoa Nova

CEP: 59072-970 Natal, RN, Brasil

E-mail: analira@ufrnet.br 


\title{
Diagnóstico de enfermagem: estratégia educativa fundamentada na aprendizagem baseada em problemas
}

Este estudo teve por objetivo avaliar a eficácia de uma estratégia de ensino sobre diagnósticos de enfermagem, fundamentada na aprendizagem, baseada em problemas no desempenho do raciocínio clínico e julgamento diagnóstico dos discentes de graduação. É estudo experimental, realizado em duas fases: validação de conteúdo dos problemas e aplicação da estratégia educativa. Os resultados mostraram melhora na capacidade de agrupamento dos dados dos discentes do grupo experimental. Conclui-se que houve influência positiva da estratégia implementada.

Descritores: Enfermagem; Diagnóstico de Enfermagem; Ensino; Aprendizagem Baseada em Problemas.

\section{Diagnóstico de enfermería: estrategia educativa fundamentada en el aprendizaje basado en problemas}

\begin{abstract}
Este estudio tuvo por objetivo evaluar la eficacia de una estrategia de enseñanza sobre diagnósticos de enfermería fundamentada en el aprendizaje basado en problemas en el desempeño del raciocinio clínico y juzgamiento diagnóstico de los estudiantes de graduación. Se trata de estudio experimental, realizado en dos fases: validación de contenido de los problemas y aplicación de la estrategia educativa. Los resultados mostraron mejoría en la capacidad de agrupamiento de los datos de los estudiantes del grupo experimental. Se concluye que hubo influencia positiva de la estrategia implementada.
\end{abstract}

Descriptores: Enfermería; Diagnóstico de Enfermería; Enseñanza; Aprendizaje Basado en Problemas.

\section{Introduction}

The decision making process in health requires that nurses be capable of thinking critically and choosing adequate actions to solve the identified problems ${ }^{(1)}$. In this process, learning clinical reasoning is one of the most complex phases in cognitive terms and one of the themes most directly involved in clinical decision making.

In this context, teaching on the nursing diagnosis process refers to the processing of clinical assessment data, to the establishment of relations among them and to the identification of care needs. Moreover, in this process, students' active participation is stimulated, so as to permit further knowledge on nursing practice ${ }^{(2-3)}$.

On the other hand, some authors defend that nursing diagnosis teaching has been conducted without providing students with critical reflection, in view of the need to develop strategies focused on gaining diagnostic skills ${ }^{(4-5)}$. The following facts different authors mention support these ideas: diagnostic teaching is not stimulated and addressed as early as the first course subjects: there is a lack of knowledge on the taxonomies used and on the physiopathology of diagnoses; students difficulty to diagnose based on a nursing reference framework, differently from the biomedical model; incipient diagnosis use in practice during academic life; and some teams, nurses and faculty members' lack of interest, which may originate in knowledge deficiencies and non understanding of the dimension diagnostic use can represent for the transformation of nursing practice $^{(2,3,6-8)}$

Although proposals have been described in literature on nursing diagnosis teaching, few studies have presented a relation between the diagnostic reasoning process as a problemization process and the search for solutions for clinical decision-making. In this respect, Problem Based Learning (PBL) is considered a teaching strategy that can contribute to support the 
establishment of the relation between diagnosing and decision-making.

It is highlighted that, although few studies exist that involve PBL and nursing diagnoses, research exists in other knowledge areas, such as medicine ${ }^{(9)}$, physical therapy(10), law ${ }^{(11)}$, geography(12), among others.

$\mathrm{PBL}$ is a method of learning through discovery which values learning how to learn. It starts with clinical situations that require a decision and tries to guide students to find solutions by learning the skills and competencies needed to identify the best actions for the problems presented ${ }^{(13)}$.

Thus, this research aimed to assess the efficacy of a teaching strategy on nursing diagnoses based on problem based learning in undergraduate students' performance of clinical reasoning and diagnostic judgment.

\section{Methods}

This experimental study was organized in two phases. The first involved problem validation and the second the application of the educative strategy on nursing diagnoses, based on problem based learning. In the first phase, the goal was to develop and validate the problems that guided the application of the educative strategy, which represented the study focus. The researchers developed four problems in the form of clinical cases. It is highlighted that, in this study, the terms "case studies" and "clinical cases", found in literature, were called "problems", in line with PBL recommendations.

In this problematizing approach, the problem constitutes a written description of the phenomena or events in reality that stimulate group learning, the activation of previous knowledge and identification of possible solutions. The problem is the fundamental component, the starting point and guideline of the learning process $^{(14)}$.

The problems the authors developed were clinical situations that covered seven NANDA International(15) domains, which were: Nutrition, Elimination and exchange, Activity/rest, Perception/cognition, Safety/ protection, Comfort and Growth/development.

Regarding content validity, the four problems were submitted to a panel of five experts, selected through criteria adapted from Fehring's ${ }^{(16)}$ scoring system. Thus, the population comprised nurses with professional qualifications at M.SC. or Ph.D. level in Nursing. In this study, experts were considered as nurses who scored at least five points on the following criteria (Figure 1).
Figure 1 - Expert selection criteria

\begin{tabular}{|l|c|}
\hline \multicolumn{1}{|c|}{ Criteria } & Score \\
\hline 1. Having an M.Sc. degree in Nursing & 1 point \\
\hline 2. Having a Ph.D. degree in Nursing & 2 points \\
\hline $\begin{array}{l}\text { 3. Having developed a Master's thesis involving nursing } \\
\text { diagnoses }\end{array}$ & 1 point \\
\hline $\begin{array}{l}\text { 4. Having developed a doctoral dissertation involving } \\
\text { nursing diagnoses }\end{array}$ & 2 points \\
\hline 5. Having publications related to nursing diagnoses & 1 point \\
\hline $\begin{array}{l}\text { 6. Participating in research groups/projects that involve } \\
\text { the theme of nursing diagnoses }\end{array}$ & 1 point \\
\hline $\begin{array}{l}\text { 7. Being a nursing faculty in subjects involving nursing } \\
\text { diagnoses }\end{array}$ & 2 points \\
\hline $\begin{array}{l}\text { 8. Having at least one year of professional experience as } \\
\text { a clinical nurse in hospitals that use the nursing process }\end{array}$ & 2 points \\
\hline
\end{tabular}

It is highlighted that, in the expert selection, both availability to participate and clinical ability for diagnostic inferences were taken into account. Among the selected experts, one scored nine and four eight.

Content validity of the problems was estimated through the mean inter-expert Content Validity Index CVI). The CVI was the mean index calculated by adding up the items all experts attributed, divided by the total number of experts. Through this method, the items and instruments on the whole are considered valid if the CVI amounts to $0.90^{(17)}$. CVI's for the four problems corresponded to $0.90 ; 0.90 ; 0.45 ; 0.55$. Hence, the last two problems needed alterations and were again forwarded to the experts. After reformulations, the problems scored CVI's of 0.90 and 0.95 .

The second study phase was the application of the educative strategy on nursing diagnoses in July 2009. Study participants were students from a Brazilian public university. Thirty students who complied with the eligibility criteria were invited to participate. All thirty accepted and were randomly distributed across two groups, experimental and control. Therefore, the thirty students were consecutively numbered. Next, a sequence of thirty numbers was written on pieces of paper of the same size, placed in a box. The box was shaken and the first fifteen numbers drawn constituted the experimental group, which participated in the educative strategy. The remainder participated in the control group and only received the standard intervention, which included theoretical and practical classes offered as part of the Semiology course in the first semester of 2009.

The inclusion criteria were: being a student in the fifth semester of the undergraduate program in Nursing; having passed the Semiology course at the same college in the first semester of 2009, and accepting to participate in all research phases. The exclusion criterion was: people who did not comply with all study phases. 
In the construction of the educative strategy, the goal was to develop a course that provided students with knowledge construction through individual and group analysis of problems. With a view to reaching this goal, PBL was used, in line with the idea(13) that this method, based on significant discovery-based learning, values learning how to learn and intentionally works with problems.

Five modules were created during the course, each of which involved a different problem, in accordance with PBL recommendations. In the first module, clinical reasoning and diagnostic judgment were discussed. In the other modules, the problems validated in the first study phase were discussed.

The course modules started with the presentation of the problem to the students, who did not have previous access to the information needed. The students worked with the problem, organized in tutorial groups. In the tutorial group, the problem was analyzed and the learning objectives were set. Then, the students started the individual study phase at the university library. The student was responsible for identifying relevant bibliographic material. The module finished with a new meeting of the tutorial group, aimed at solving the problem. At that time, the group members systematically presented the results of their individual study and reviewed and systemized the final proposals for the problem.

To assess the effectiveness of the course, the researchers decided to use a strategy similar to that of the problems discussed during the course modules, with a view to continuing coherence with PBL principles. Thus, course effectiveness was assessed through a pre and post-test, based on the scores the 30 students obtained on each test. For the pre and post-test, two problems were used that had been validated in an earlier study ${ }^{(18)}$.

The study variables were: gender, nursing experience before undergraduate program, age, defining characteristics, related factors and labels of the nursing diagnoses. Data were compiled in Excel worksheets, while SPSS version 16.0 was used for statistical analysis.

Data were organized in tables and analyzed based on absolute frequencies, as central trend and dispersion measures, association tests and differences of means. The Kolmogorov-Smirnov test was applied to the numerical variables to check the normality of numerical data, and the Levene test to check the homogeneity of variances. To assess the variables' independence, the Chi-square test was used. Fisher's exact test was used when the expected frequencies were lower than or equal to five. The chance ratio and its confidence intervals were also calculated. For comparisons of means, the t-test was applied, supposing equal or unequal variances, depending on the result of the application of the Levene test. In case of data asymmetry, Mann-Whitney's test was applied. To assess for intragroup mean differences, the paired t-test was applied. For all inferential calculations, significance was set at 0.05 .

Regarding ethical aspects, authorization for the study was obtained from the dean's office of the academic unit involved. Then, it was forwarded to the Institutional Review Board. In compliance with recommendations of Resolution 196/96 for research involving human beings, approval was obtained under Protocol No. 217/09. In addition, all participants were informed about the goals set and signed the informed consent term.

\section{Results}

Study participants were thirty students in the fifth semester of the undergraduate program in Nursing. None of the students dropped out during the research. Next, in Table 1, the students' socio-demographic data are presented.

Table 1 - Distribution of students according to sociodemographic data $(n=30)$. Natal-RN, 2009

\begin{tabular}{lccc}
\hline \multicolumn{1}{c}{ Variables } & $\begin{array}{c}\text { Experimental } \\
\text { Group }(\mathbf{n}=\mathbf{1 5})\end{array}$ & $\begin{array}{c}\text { Control } \\
\text { Group }(\mathbf{n = 1 5})\end{array}$ & Statistics \\
\hline $\begin{array}{l}\text { Gender } \\
\text { Female }\end{array}$ & 12 & 12 & $\mathrm{p}=1.000^{1 \text { * }}$ \\
Male & 3 & 3 & \\
Previous nursing experience & & & \\
Yes & 3 & 4 & $\mathrm{p}=1.000^{*}$ \\
No & 12 & 11 & \\
Age & & & \\
Mean & 21.4 & 22.0 & $\mathrm{p}=0.313^{\dagger}$ \\
SD & 1.92 & 1.195 & \\
P-value (K-S) & 0.700 & 0.595 & \\
\hline
\end{tabular}

* Fisher Test; ${ }^{\dagger}$ t Test supposing equal variances; SD - Standard deviation K-S- Kolmogorov-Smirnov test

The analysis of the socio-demographic variables revealed the following: predominance of the female gender $(80 \%)$, single $(93.3 \%)$, Catholics (93.3\%), without previous experience in nursing (76.7\%) and with a mean age of 21.7 years. Regarding socio-demographic data, the experimental and control groups showed similar means $(p>0.05)$.

The results of the pre-test application showed that the identification of the defining characteristics among 
students in the experimental and control groups was similar, as all 14 defining characteristics scored $p$-values above the significance level ( $p>0.05)$, without statistical differences. A similar fact occurred for the identification of the nursing diagnoses and related factors. In the experimental as well as in the control group, the most identified nursing diagnosis was Excess fluid volume. Only the related factor Compromised regulatory mechanisms showed a statistically significant difference $(p=0.035)$, with more frequent identifications among students in the experimental group.
On the post-test, it was observed that the identification of defining characteristics among students in the experimental and control groups was similar ( $p>0.05$ ). On the other hand, the identification of the diagnoses Risk for infection $(p=0.001)$ and Risk for aspiration $(p=0.042)$ was associated with the experimental group. In addition, the identification of the related factors Increased environmental exposure $(p=0.042)$ and Invasive Procedures $(p=0,001)$ was also more frequent in the experimental group.

Table 2 shows the mean number of characteristics, diagnoses and related factors both groups identified.

Table 2 - Analysis of differences in means between the number of defining characteristics, nursing diagnoses and related factors students identified in the experimental and control groups. Natal-RN, 2009

\begin{tabular}{|c|c|c|c|c|c|c|}
\hline \multirow{2}{*}{ ND Components } & \multicolumn{2}{|c|}{ Experimental Group } & \multicolumn{2}{|c|}{ Control Group } & \multicolumn{2}{|c|}{ Statistics } \\
\hline & Pre-test & Post-test & Pre-test & Post-test & Pre-test & Post-test \\
\hline \multicolumn{7}{|l|}{ Total of DC } \\
\hline Mean & 3.40 & 1.67 & 2.20 & 0.73 & $p=0.180^{*}$ & $p=0.202^{\dagger}$ \\
\hline SD & 2.823 & 1.799 & 1.859 & 1.223 & & \\
\hline P-value (K-S) & 0.857 & 0.162 & 0.492 & 0.20 & & \\
\hline \multicolumn{7}{|l|}{ Total of ND } \\
\hline Mean & 1.13 & 1.80 & 0.80 & 0.73 & $p=0.291$ * & $p=0.010^{*}$ \\
\hline SD & 0.990 & 0.862 & 0.676 & 0.704 & & \\
\hline P-value (K-S) & 0.169 & 0.160 & 0.181 & 0.300 & & \\
\hline \multicolumn{7}{|l|}{ Total of RF } \\
\hline Mean & 1.07 & 2.47 & 0.67 & 0.73 & $p=0.186^{*}$ & $p=0.000^{*}$ \\
\hline SD & 0.961 & 1.125 & 0.617 & 0.884 & & \\
\hline P-value (K-S) & 0.587 & 0.259 & 0.122 & 0.76 & & \\
\hline
\end{tabular}

DC- Defining Characteristic; ND- Nursing diagnosis; RF- Related factor; SD- Standard Deviation; K-S- Kolmogorov-Smirnov test; *t Test supposing equal variances; ${ }^{+}$Mann-Whitney test.

No differences were identified in the mean number of defining characteristics, nursing diagnoses and related or risk factors experimental and control group students identified in the pre-test. On the other hand, students from the experimental group identified a higher mean number of diagnoses $(p=0.010)$ and related factors $(p=0.000)$ in the post-test.

Table 3 presents the analysis of differences between the mean pre and post-test scores, between and inside the experimental and control groups.

Table 3 - Analysis of differences in mean pre-test and post-test scores inter and intra-experimental and control groups. Natal-RN, 2009

\begin{tabular}{|c|c|c|c|c|c|c|}
\hline \multirow[t]{2}{*}{ Scores } & \multicolumn{2}{|c|}{ Experimental Group } & \multicolumn{2}{|c|}{ Control Group } & \multicolumn{2}{|c|}{ Between Groups } \\
\hline & Pre-test & Post-test & Pre-test & Post-test & Pre-test & Post-test \\
\hline Mean & 1.74 & 4.42 & 1.27 & 1.34 & $p=0,406^{*}$ & $p=0,000^{\dagger}$ \\
\hline SD & 1.56 & 2.35 & 1.48 & 1.44 & & \\
\hline P-value (K-S) & 0.346 & 0.612 & 0.097 & 0.161 & & \\
\hline Intra-group & \multicolumn{2}{|c|}{$p=0.001 \ddagger$} & \multicolumn{2}{|c|}{$p=0.919 \ddagger$} & & \\
\hline
\end{tabular}

K-S- Kolmogorov-Smirnov test; * t Test supposing equal variances; ${ }^{+} \mathrm{t}$ Test supposing unequal variances; ${ }^{\ddagger}$ Paired $\mathrm{t}$-test 
Scores ranged from zero to ten. When comparing the mean scores, no statistically significant difference was identified between the experimental and control groups ( $p=0.406)$. On the post-test, however, the experimental group's mean scores were statistically higher in comparison with the control group's mean scores ( $p<0.001)$. Intragroup assessment of the mean pre and post-test scores showed a statistically significant difference for experimental group scores only $(p=0.001)$.

\section{Discussion}

As for socio-demographic data, the results showed that similar profiles for experimental and control group students before the educative intervention. That minimizes one of the limitations described in one study ${ }^{(19)}$, in which the sample comprised a disproportionally higher number of students from the final two semesters of the nursing course. According to the same author, the presence of students with different experience or skill levels could affect the study results. Initial uniformity between groups is also important to control for variations in knowledge and previous experience.

On the pre-test, high frequencies were found for the identification of the Excess fluid volume diagnosis among students in both groups. This can be explained by the fact that frequent discussions existed on the defining characteristics involved in this diagnosis - such as edema, blood pressure, breathing, jugular vein turgor, among others - during theoretical and practical classes as part of the Semiology and Physiology subjects.

On the post-test, students from the experimental group evidenced the Risk for infection diagnosis and its risk factors more frequently than in the control group.

In a study accomplished in Japan(20), two written case studies were used to verify 376 nurses' diagnostic reasoning competency. The study showed that $50 \%$ of these nurses correctly identified the Risk for infection diagnosis and $84 \%$ its risk factors. According to the authors, that diagnosis is used very frequently in Japan.

In the Brazilian reality, the Risk for infection diagnosis is also discussed quite frequently, mainly when the students learn the nursing procedures that need antisepsis and asepsis care, such as urinary probing for example, during the Semiology subject.

These study results show that the post-test identification of defining characteristics among students from both groups was similar and with low frequencies.
One justification for the small number of defining characteristics students in the two groups identified was that defining characteristics in problem B used for the post-test were written differently from those presented in Nanda International's Taxonomy II; the researchers believe this may have jeopardized the understanding of incipient students in the nursing diagnosis elaboration process.

In a study involving 55 nursing students, aimed at analyzing the relation between cognitive development, clinical knowledge and clinical experience, two clinical cases from the maternal-infant area were used(19). The students did not manage to identify many nursing diagnoses. In clinical cases 1 and 2, there were 16 and 11 answer possibilities, respectively. The students identified a mean 3.27 on the first simulation and 1.43 on the second. These data are similar to the present study findings.

In the groups under assessment, a statistically significant difference was perceived between experimental group students' scores on the pre and post-test. On the other hand, in the control group, no such statistically significant difference was found between mean scores on both tests.

Also similar to the present study, in a study accomplished in São Paulo(21), students from the experimental group showed a significant improvement during the post-intervention phase for the three activities assessed (identify relevant data, group data and name the grouping) in comparison with control group participants. This suggests that the course exerted positive influence on students' diagnostic reasoning.

As the main study limitations, the small sample should be highlighted. Regarding the course, the period it took place and its intensive nature may have entailed different conditions for students in both groups. It is highlighted that the course was held during the students' last week of holidays. Study activities for experimental group participants took one week, during the morning and afternoon periods. These factors may have caused different conditions for experimental and control group students, as the latter were on holiday and returned to college for the post-test. On the other hand, experimental group students were finishing the course, in a study environment, when they took the post-test, which could stimulate their motivation to accomplish the requested procedures. It is also highlighted that, despite taking the course, the thirty students' mean scores are very low, demonstrating the need for continuous training. And, finally, the related factor Compromised 
regulatory mechanisms, present on the pre-test, was more identified in the experimental group, which could identify these students' better knowledge in comparison with the control group.

Some difficulties were faced to accomplish this study. The first was related to the development of problems that involved clients' typical clinical situations, which the undergraduate students should be familiar with and have previous knowledge about. The second difficulty was that problem development took a lot of time and required great effort to achieve a range of nursing diagnoses. And, finally, the lack of publications on nursing diagnosis teaching strategies through problem-based learning hampered data discussion.

Further research is suggested, with a view to the creation of teaching strategies that address other classification systems, based on a common language, linked with the elements of the nursing process, at undergraduate as well as graduate level. This will cooperate for nursing to take hold of its own knowledge base in an organized way, according to its work method.

\section{Conclusion}

This study permitted assessing the efficacy of an educative strategy on nursing diagnoses based on PBL, using a pre and post-test. On the pre-test, the two groups identified the characteristics, diagnoses and related factors homogeneously. On the other hand, as expected, students from the experimental group identified more nursing diagnoses and related or risk factors on the post-test. Although students from both groups identified few defining characteristics on the post-test, one may conclude that the educative strategy on nursing diagnoses based on PBL seems to have enhanced undergraduate students' clinical reasoning and diagnostic judgment, as the results showed improved data grouping capacity among experimental group students.

This study contributed by using PBL as a teaching strategy to help and establish undergraduate students' clinical reasoning and diagnostic judgment. PBL allows students to construct their own knowledge through the analysis of problems in tutorial groups as well as individually.

\section{References}

1. Lima MAC, Cassiani SHB. Pensamento crítico: um enfoque na educação de enfermagem. Rev. Latino-Am. Enfermagem. 2000;8(1):23-30.
2. Cruz DALMC. Diagnóstico de enfermagem: qual a abordagem no novo currículo? In: Guedes MVC, Araujo $\mathrm{TL}$, organizadores. $\mathrm{O}$ uso do diagnóstico na prática de enfermagem. 2 ed. Brasília: Associação Brasileira de Enfermagem; 1997. p. 100-5.

3. Silva AGI. Ensinando e cuidando com o processo diagnóstico em enfermagem. Belém: Smith Produções Gráficas; 2001.

4. Nakatani AYK, Carvalho EC, Bachion MM. O ensino de diagnóstico de enfermagem através da pedagogia da problematização. Rev Eletrônica Enferm. [periódico na Internet]. 2000;2(1). [acesso 20 nov 2010]. Disponível em: http://www.fen.ufg.br/revista

5. Carvalho EC. Diagnóstico de enfermagem: considerações sobre seu ensino. In: Guedes MVC, Araujo $\mathrm{TL}$, organizadores. O uso do diagnóstico na prática de enfermagem. 2 ed. Brasília: Associação Brasileira de Enfermagem; 1997. p. 59-69.

6. Carvalho EC, Bachion MM, Ferraz AEP, Veiga EV, Ruffino MC, Robazzi MLCC. O processo de diagnosticar e o seu ensino. Rev Esc Enferm USP. 1996;30(1):33-43.

7. Lopes MHBM, Vale IN, Barbosa M. Opinião dos alunos quanto ao ensino dos diagnósticos de enfermagem segundo a taxonomia da NANDA. Rev Esc Enferm USP. 1997;31(1):80-8.

8. Almeida MA. Competências e o processo ensinoaprendizagem do diagnóstico de enfermagem: concepções de docentes e discentes [tese de doutorado]. Porto Alegre (RS): Faculdade de Educação da Pontifícia Universidade Católica do Rio Grande do Sul; 2002. 245 p.

9. Barro NF, Lourenço LCA. O Ensino da saúde coletiva no método de aprendizagem baseado em problemas: uma experiência da Faculdade de Medicina de Marília. Rev Bras Educ Méd. 2006;30(3):136-46.

10. Macedo R. Concepções e sentimentos em relação à Aprendizagem Baseada em Problemas (ABP): estudo do caso dos estudantes de fisioterapia da Escola Superior de Tecnologias da Saúde do Porto. EssFisiOnline. 2009;5(2):34-54.

11. Arantes AC, Mussi AA. Aplicação do PBL no ensino do direito (uma experiência). Vox Forensis. 2010;3(2):22-40.

12. Moraes JV. A alfabetização científica, a resolução de problemas e o exercício da cidadania: uma proposta para o ensino de geografía [tese de doutorado]. São Paulo (SP): Faculdade de Educação da Universidade de São Paulo; 2010. 246 p.

13. Cyrino EG, Pereira MLT. Trabalhando com estratégias de ensino-aprendizado por descoberta: a problematização e a aprendizagem baseada em problemas. Cad Saúde Pública. 2004;20(3):780-8. 
14. Mamede S. Aprendizagem baseada em problemas: características, processos e racionalidade. In: Mamede S, Penaforte J, Schmidt H, Capra A, Tomza JB, Sa H. Aprendizagem baseada em problemas: anatomia de uma nova abordagem educacional. Fortaleza: Hucitec; 2001.

15. North American Nursing Diagnosis Association (NANDA). Diagnósticos de enfermagem da NANDA: definições e classificações 2007-2008. Porto Alegre: Artmed; 2008.

16. Fehring R. Methods to validate nursing diagnosis. Heart \& Lung. 1987;16(6):625-9.

17. Waltz CF, Strickland OL, Lenz ER. Measurement in nursing research. 2nd.ed. Philadelphia: Davis; 1991.

18. Cruz DALM. A introdução do diagnóstico de enfermagem: sua influência no processamento de informações por alunos de graduação [tese de doutorado]. São Paulo (SP): Escola de Enfermagem de Ribeirão Preto da Universidade de São Paulo; 1995. 125 p.

19. Aquilino ML. Cognitive development, clinical knowledge, and clinical experience related to diagnostic ability. Nurs Diagn. 1997;8(3):110-9.

20. Hasegawa T, Ogasawara C, Katz EC. Measuring diagnostic competency and the analysis of factors influencing competency using written case studies. Int J Nurs Terminol Classif. 2007;18(3):93-102.

21. Cruz DALM, Arcuri EAM. The influence of nursing diagnosis on information processing by undergraduate students. Nurs Diagn. 1998;9(3):93-100. 